\title{
THE THIRD SECTOR AND THE NEW DEVELOPMENT PARADIGMS
}

\begin{abstract}
Valentin FILIPa*
a) Babeş-Bolyai University, Faculty of Economics and Business Administration, Cluj-Napoca, Romania and Program Director, Civitas Foundation for Civil Society, Cluj-Napoca Branch
\end{abstract}

Please cite this article as:

Article History:

Filip, V., 2020. The third sector and the new Received: 10 May 2020 development paradigms. Review of Economic Accepted: 30 September 2020 Studies and Research Virgil Madgearu, 13(2), pp.67-85.

doi: 10.24193/RVM.2020.13.61.

Abstract: NGOs, as economic actors, are now passing a stage that could change their role in development for the long term. Developing NGOs are not only making peace with the market but are using its mechanisms to better tackle challenges such as poverty, inequality, democratic participation and bottom-up empowerment. Development projects are more sensible to the market needs and evolution while economic sustainability of their results is now a prerequisite. Furthermore, efficiency and accountability are criteria that appear in the majority of funding entities calls for projects, all of this putting a pressure on NGOs for changing their practices, their staff competences and their strategies. This evolution, perceived from the perspective of development economics theories, is contributing the confirmation of the "market solutions" approach, given by the neoliberal theories. However it is important to say that NGOs are making a selection of some large areas that can become a "refined" neoliberalism.

Key words: development economics; NGOs; market mechanisms; alternatives to development

JEL Classification: $O 21 O$

(C) 2020 Alma Mater Publishing House. All rights reserved.

* Corresponding author. E-mail address: valentin@civitas.ro. 
Review of Economic Studies and Research Virgil Madgearu, 2020, 13(2)

\section{References:}

1. Baker, B., 2011. World Development: An essential text. Oxford: New Internationalist.

2. Banerjee, A.V. and Duflo, E., 2011. Poor Economics. London: Penguin Books.

3. Banks, N. and Hulme, D., 2012. The Role of NGOs and Civil Society in Development and Poverty Reduction. Brooks World Poverty Institute Working Paper No. 171.

4. Bebbington, A., Hickey, S. and Mitlin, D.C. (eds), 2007. Can NGOs Make a Difference? The Challenge of Development Alternatives. London: Zed Books.

5. Christensen, C.M., Ojomo, E. and Dillon, K., 2020. Paradoxul prosperității: cum pot invațiile să scoată popoarele din sărăcie. București: Publica.

6. Clark, C., Emerson, J. and Thornley, B., 2015. The impact investor: lessons in Leadership and Strategy for Collaborative Capitalism. San Francisco: Jossey-Bass.

7. Dunning, J.H., 2006. Towards a new paradigm of development: implications for the determinants of international business. Transnational Corporations, 15(1), p.173+. Gale Academic One File. Accessed 07 April 2020.

8. Epstein, G.S. and Gang I.N., 2006. Contests, NGOs, and Decentralizing Aid. Review of Development Economics, 10(2), pp.285-296. https://doi.org/10.1111/j.1467-9361.2006.00318.x.

9. Easterly, W., 2013. The Tyranny of experts. New York: Basic Books.

10. Gibson, C.C., 2005. The Samaritan Dilemma: The Political Economy of Development Aid. New York: Oxford University Press.

11. Hulme, D. and Edwards, M. (eds), 2013. NGOs, States and Donors, Too close for Comfort? New York: Palgrave Macmillan.

12. Impact Hub Newtork (online) https://impacthub.net/ [Accessed o7 April 2020].

13. Korten, D., 1990. Getting to the 21st Century: Voluntary Action and the Global Agenda. Sterling: Kumarian Press.

14. Lewis, D. and Kanji, N., 2009. Non-Governmental Organisations and Development. Oxford: Routledge.

15. Moyo, D. 2011. How the West was Lost. London: Penguing Books. 
16. Powell, W.W., Steinberg, R. (eds), 2006. The Non-profit Sector, A Research Handbook, Second Edition. New Heaven: Yale University Press.

17. Yunus, M., 2010. Building Social Business: The New Kind of Capitalism that Serves Humanity's Most Pressing Needs. NewYork: Public Affairs. 